\title{
TWO NEW SPECIES OF THE GENUS HALAPHANOLAIMUS DE MAN, 1876 (NEMATODA: LEPTOLAIMIDAE) FROM CANGIO MANGROVE FOREST, VIETNAM
}

\author{
VLADIMIR G. GAGARIN \\ Institute of Inland waters Biology of Russian Academy of Science, Russia \\ NGUYEN VU THANH \\ Institute of Ecology and biological Resources, Vietnam
}

\begin{abstract}
SUMMARY
New brackish water nematode species Halaphanolaimus cangionensis sp.nov, and Halaphanolaimus rivalis sp.nov collected from Cangio mangrove forest, Hochiminh city of Vietnam are described. Halaphanolaimus cangionensis sp.nov is characterized by the absence of somatic and cervical setae, comparatively slender tail, presence of caudal apophysis of the gubernaculum and comparatively short spicules. New species Halaphanolaimus cangionensis sp.nov resembles to Halaphanolaimus harpaga Boucher, Bovee, 1972 and Halaphanolaimus luridus (Timm, 1963) but differs from H. harpaga by the absence of somatic and cervical setae, more anterior position of vulva, another structure of gubernaculums and other arrangement of precloacal supplements. The new species differs from $H$. luridus by the more slender tail, longer stoma, another structure of gubernaculums and shorter spicules. Halaphanolaimus rivalis sp.nov is characterized by the presence of somatic and servical setae, long spicules and pre-equatorial vulva. New species Halaphanolaimus rivalis sp.nov, resembles to Halaphanolaimus luridus (Timm, 1963) and L. lorenzeni Boucher, Bovee, 1972 but $H$. rivalis sp.n. differs from $H$. luridus by the presence of somatic and cervical setae, more wide labial region, longer stoma, shorter spicules. H. rivalis sp.n. differs from H. lorenzeni by the thicker body, longer stoma and longer spicules. Key to six valid species of the genus Halaphanolaimus are given.
\end{abstract}

Key words: Nematoda, Halaphanolaimus, new species, Cangio mangrove, Vietnam.

Fauna of free-living brackish water and marine nematodes of Vietnam is studied recently. At present, this investigating field on nematode biodiversity is strongly improved, in connection with creating of the new database for the biomonitoring assessment of water quality in watershed and wetland ecosystems of whole Vietnam. This work is a part of the Vietnam National Project for study of biodiversity and free-living nematode fauna of the Cangio mangrove forest, belongs to the Hochiminh city of Vietnam during 2000-2005 years. Cangio mangrove forest located in the South of Hochiminh city, Vietnam with latitude: $10^{\circ} 22^{\prime} 14^{\prime \prime}-10^{\circ} 40^{\prime} 09^{\prime \prime}$ and longitude: $106^{\circ} 46^{\prime} 12^{\prime \prime}-107^{\circ} 00^{\prime} 59^{\prime \prime}$. The nematode samples were collected at the March and April 20022004, In this paper, two new species of the Leptolaimidae, Halaphanolaimus cangionensis sp.nov, Halaphanolaimus rivalis sp.nov are described.

\section{MATERIAL AND METHODS}

Samples are done from a boat using a Ponar grab. In each station one grab is collected with three replicated for nematodes analysis, all samples are fixed in hot formalin $10 \%$. The nematodes are extracted by LUDOX - TM 50 solution with centrifugation method and gradually transferred to anhydrous glycerin and finally mounted into permanent slides. 
Abbreviation used in the text:

L. total body length $(\mu \mathrm{m})$; a. body length divided by maximum body width; b. body length divided by pharyngeal length; c. body length divided by tail length; c'. tail length measured in cloacal body diameters; V. relation of distance from anterior body end to vulva for body length at per cent.

\section{DESCRIPTION}

\section{Halaphanolaimus cangionenisis sp.nov (fig.1)}

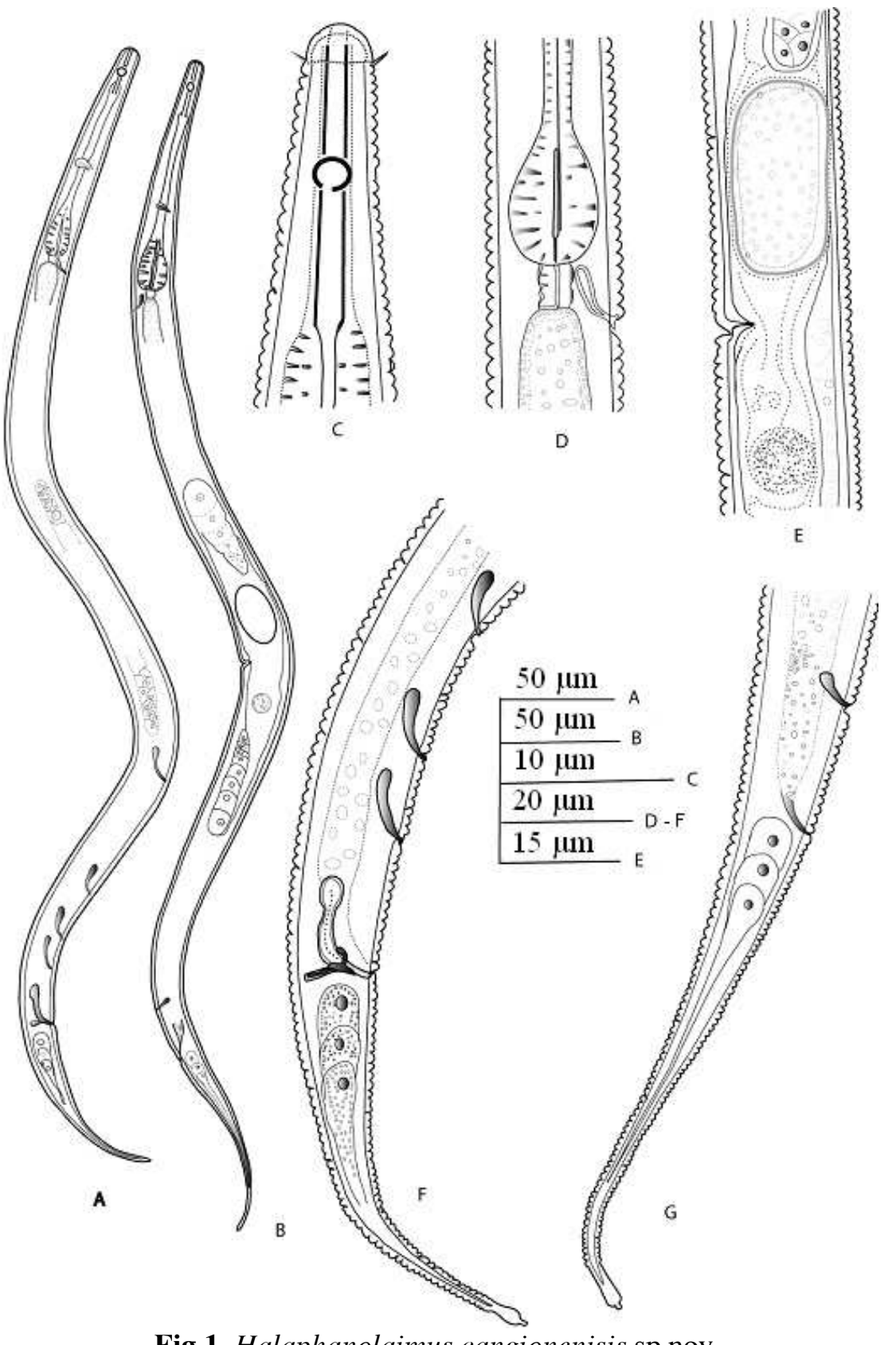

Fig.1. Halaphanolaimus cangionenisis sp.nov

A. Entire male; B. Entire female; C. Head region; D. Cardial region of male; E. Vulva region; F. Posterior end of male; G. Posterior end of female. 
Measurements: Table 1.

Female: small, slender worms. Cuticle coarse annulated; annules 1.2-1.5 $\mu \mathrm{m}$ wide. Thickness of cuticle in vulva region about 1.0 $\mu \mathrm{m}$. Lateral fields 1.3-1.5 wide, extend from middle of oesophagus length to one a third of tail length. Somatic setae absent. Labial region isolated from the rest of body. Labial papillae not visible. Four cephalic setae 1.5-2.0 $\mu \mathrm{m}$ long, disposed in the base of labial region. Amphidial fovea in form of the circle turn below, 1.8-2.0 $\mu \mathrm{m}$ in diameter, its anterior margin situated 7,0$8,0 \mu \mathrm{m}$ from anterior body end. Stoma narrow and long tube-shaped, $14-18 \mu \mathrm{m}$ long (3.5-4.5 labial region width). Oesophagus slender, muscular, basal bulb well developed, its length approximately equal to corresponding body width. Ventral gland, its canal and excretory pore not observed. Cardia muscular, 6.5-8.5 $\mu \mathrm{m}$ long. One tubular supplement 8.0-8.5 $\mu \mathrm{m}$ long, situated ventrally at level of intestine beginning. This tubular supplement absent at two females. Rectum length shorter than anal body width. One tubular supplement situated ventrally at distance 20-21 $\mu \mathrm{m}$ (1.8-1.9 anal body width) from anus. Reproductive system didelphic, amphidelphic; ovaries antidromous. Vulva as a rule praequatorial. Vagina situated perpendicularly to longitudinal axis of the body; its length approximately equal to one a third of corresponding width. One or two eggs in uterus, $36-39 \times 15-17 \mu \mathrm{m}$. Tail slender, gradually narrowing. Papillae and setae at tail absent. Terminus of tail smooth, not annulated and slightly swollen. Caudal glands and spinneret well developed.

Table 1

Measurements of Halaphanolaimus cangionensis sp.nov (all measurements in $\mu \mathrm{m}$, exept ratio)

\begin{tabular}{|c|c|c|c|c|c|}
\hline \multirow{3}{*}{ Characteristics } & \multirow{3}{*}{$\begin{array}{c}\text { Holotype } \\
0 \\
\lambda\end{array}$} & \multicolumn{4}{|c|}{ Paratypes } \\
\hline & & \multicolumn{2}{|c|}{$11 \circlearrowleft \sigma^{\lambda}$} & \multicolumn{2}{|c|}{13 우우 } \\
\hline & & range & mean & range & mean \\
\hline $\mathrm{L}$ & 537 & $502-571$ & 532 & $499-570$ & 535 \\
\hline $\mathrm{a}$ & 32 & $28-37$ & 32 & $24-30$ & 27 \\
\hline $\mathrm{b}$ & 5.1 & $4.7-5.5$ & 5.2 & $4.9-5.5$ & 5.2 \\
\hline $\mathrm{c}$ & 6.6 & $6.6-7.6$ & 7.0 & $5.7-7.1$ & 6.3 \\
\hline$c^{\prime}$ & 5.8 & $5.0-6.3$ & 5.5 & $6.8-8.1$ & 7.4 \\
\hline $\mathrm{V} \%$ & - & - & - & $47.2-50.4$ & 48.3 \\
\hline Oesophagus length & 106 & $101-106$ & 103 & $90-107$ & 103 \\
\hline $\begin{array}{l}\text { Posterior end of oesophagus to } \\
\text { vulva }\end{array}$ & - & - & - & $136-182$ & 155 \\
\hline Vulva to anus & - & - & - & $175-203$ & 192 \\
\hline $\begin{array}{l}\text { Posterior end of oesophagus to } \\
\text { cloaca }\end{array}$ & 350 & $322-388$ & 353 & - & - \\
\hline Tail length & 81 & $70-84$ & 76 & $76-91$ & 85 \\
\hline Labial region width & 4.0 & $3.5-4.0$ & 4.0 & $3.5-4.5$ & 4.0 \\
\hline Stoma length & 18 & $15-18$ & 17 & $14-18$ & 16 \\
\hline Cephalic setae length & 2.0 & $1.5-2.0$ & 1.75 & $1.5-2.0$ & 1.8 \\
\hline Amphid fovea to body head & 8.0 & $7.0-8.0$ & 7.5 & $7.0-8.0$ & 7.5 \\
\hline Spicules length (along arch) & 17 & 16-18 & 17 & - & - \\
\hline
\end{tabular}

Male: cuticle coarse annulated. Lateral fields extend from middle of oesophagus to one a third of tail length. Somatic setae absent. Labial region isolated from the rest of body.
Labial papillae not visible. Cephalic setae 1.5$2.0 \mu \mathrm{m}$ long, situated in the base of labial region. Amphidial fovea in form of the circle, torn below, about $2.0 \mu \mathrm{m}$ in diameter, its 
anterior margin situated 7.0-8.0 $\mu \mathrm{m}$ from anterior body end. Stoma in form narrow tube, 15-18 $\mu \mathrm{m}$ long. Oesophagus slender, muscular with well developed basal bulb. Cardia muscular, 7.0-9.0 $\mu \mathrm{m}$ long. One tubular supplement situated at level of the intestine beginning. This tubular supplement absent at one male. Testes paired, opposed. Spicules paired, strongly curved, with well developed capituli. Gubernaculum with one dorsal apophysis and two narrow ventral apophyses. Precloacal ventromedian supplements in form cuticularized tubes, 11-13 $\mu \mathrm{m}$ long, 4 in number always. Supplements situated at different distance one after another. The longest distance being between fourth and third supplements. Distance between supplements (at brackets being the mean quantities). Cloaca to fourth, 1822(20) $\mu \mathrm{m}$; fourth to third 11-17(15) $\mu \mathrm{m}$; third to second, 19-23(20) $\mu \mathrm{m}$; second to first, 4376(55) $\mu \mathrm{m}$. Common length of supplemental row being 93-126 $\mu \mathrm{m}$. Papillae or setae at precloacal region between supplements absent. Tail slender, gradually narrowing. Caudal setae absent. Tail-tip slightly swollen and smooth, not annulated. Caudal glands and spinneret well developed.

Type locality and habitat: Thi Vai river, mangrove forest Cangio, Hochiminh city, Vietnam. Depth of watrs 1.5-4.5 m, fine silt, salinity $16-25 \hat{\mathrm{E}}$.

Type material: holotype male on slide number 48/II and paratypes $3 \hat{\delta} \bar{\delta}$ and 4 q $Q$ on slide $48 \mathrm{~b} / \mathrm{II}$ deposited at the nematode collection of the Institute of Inland Waters Biology, Borok,

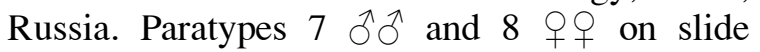
$48 \mathrm{c} / \mathrm{II}$ deposited at the nematode collection of the Institute of Ecology and biological Resources, Vietnamese Academy of Science and Technology, Hanoi, Vietnam

Differential diagnosis: the new species resembles to Halaphanolaimus harpaga Boucher, Bovee, 1972 and Halaphanolaimus luridus (Timm, 1963) but differs from $H$. harpaga by the absence of somatic and cervical setae, more anterior position of vulva (in $H$. harpaga, $\mathrm{V}=51-53 \%$ in new species $\mathrm{V}=$ 47.2-50.4\%), another structure of gubernaculums and other arrangement of precloacal supplements (Boucher, Bovee, 1972). The new species differs 10 from $H$. luridus by the more slender tail (in $H$. luridus, c' $=4.0-4.5$ vs c' $=5,0-8,1$ in the new species), longer stoma (in $H$. luridus, stoma $8 \mu \mathrm{m}$ vs $14-18 \mu \mathrm{m}$ in new species), another structure of gubernaculums and shorter spicules (in $H$. luridus, spicules $35 \mu \mathrm{m} v s$ 16-18 $\mu \mathrm{m}$ in new species) (Timm, 1963).

Etymology: the species is refered to its type locality: Cangio mangrove forest of Vietnam.

\section{Halaphanolaimus rivalis sp.nov (Fig.2)}

\section{Measurements: Table 2.}

Female: Small, slender worms. Cuticle coarse annulated, annules $1.5 \mu \mathrm{m}$ wide. Thickness of cuticle 1.0-1.5 $\mu \mathrm{m}$, lateral fields about $1.5 \mu \mathrm{m}$ wide, extend from middle of oesophagus length to one a third of tail length. Somatic setae situated at cervical region and at the tail. Labial region isolated from the rest of body. Labial papillae not visible. Four cephalic setae about 3.0-3.5 $\mu \mathrm{m}$ long (50\% of labial region width) disposed in the base of labial region. Amphidial fovea in form of the torn below circle, $3.0 \mu \mathrm{m}$ in diameter, its anterior margin situated 6.5-7.5 $\mu \mathrm{m}$ from anterior body end. Cervical setae short, $2 \mu \mathrm{m}$ long. Stoma in form of the narrow and long tube, 21-22 $\mu \mathrm{m}$ long (3.3-3.5 lip region width). Oesophagus slender, muscular, its basal bulb well developed, pear-shaped, its length approximately equal to corresponding body width. Ventral glands cell, its canal and excretory pore not observed. Cardia muscular, 7-9 $\mu \mathrm{m}$ long. One tubular supplement, $11 \mu \mathrm{m}$ long, situated ventrally at level of intestine beginning. Rectum length slightly shorter than anal body diameter. Anal opening hardly observed. One tubular supplement situated ventrally, at distance 31-35 $\mu \mathrm{m}$ from anus (3.0-3.5 anal body width). Reproductive system didelphic, amphidelphic, with an ovaries antidromous. Vulva pre-equatorial. Vagina situated perpendicularly to longitudinal axis of the body, its length approximately an equal to one a third of corresponding body width. Tail slender, gradually narrowing. Tail tip smooth, not annulated and slightly swollen, with 3-4 short setae $2 \mu \mathrm{m}$ long situated at the tail. Caudal glands and spinneret well developed. 

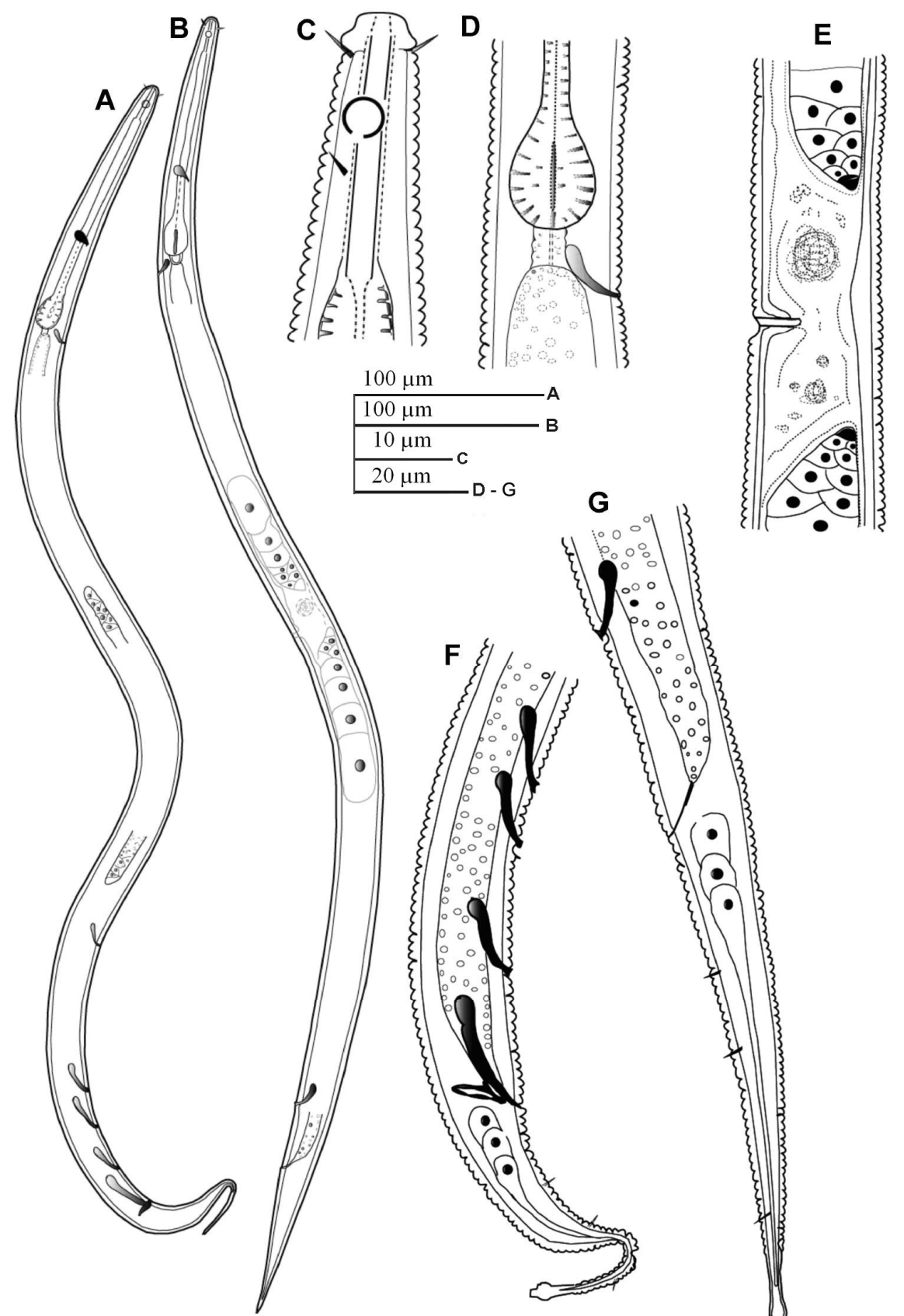

Fig. 2. Halaphanolaimus rivalis sp.nov

A. Entire male; B. Entire female; C. Head region; D. Oesophagus bulb;

E. Vulva region; F. Spicule structure with precloacal supplements; G. Tail of female.

Male: similar to females in general morphology. Cuticle coarse annulated. Lateral fields extend from middle of oesophagus to one a third of tail length. Labial region isolated from the rest of body. Labial papillae not visible. Cephalic setae 3.0-3.5 $\mu \mathrm{m}$ long. Cervical setae 2 $\mu \mathrm{m}$ long. Amphidial fovea in form of the circle, torn below, $3.0 \mu \mathrm{m}$ in diameter, its anterior margin situated 7.0-8.0 $\mu \mathrm{m}$ from anterior body end. Stoma in form narrow tube, 19-21 $\mu \mathrm{m}$ long. Oesophagus slender, muscular, its basal bulb well developed. Cardia muscular, 7-9 $\mu \mathrm{m}$ long. 
One tubular supplement, 12-13 $\mu \mathrm{m}$ long, situated at intestine beginning. One setae, $3 \mu \mathrm{m}$ long, disposed in front of the cloaca. Testes paired, opposed. Spicules paired, strongly curved, with well developed capituli. Gubernaculum with one caudal apophysis. Precloacal ventromedian supplements in form cuticularized tubes, 14-18 $\mu \mathrm{m}$ long 4 in number always. Supplements situated at different distance one after another. The longest distance being between first (the distantest from cloaca) and second supplement; the smallest distance being between second and third supplements. Distance between supplements (at brackets being the mean quantities): cloaca to fourth, 2528(27) $\mu \mathrm{m}$; fourth to third, 22-30(25) $\mu \mathrm{m}$; third to second, 13-17(14) $\mu \mathrm{m}$; second to first, 7694(86) $\mu \mathrm{m}$. Common length of supplement row being 149-158 $\mu \mathrm{m}$. Papillae and setae at precloacal region between supplements absent. Tail slender, gradually narrowing. Tail armed 35 short setae, $2 \mu \mathrm{m}$ long. Tail tip smooth, not annulated and slightly swollen. Caudal glands and spinneret well developed.

Table 2

Measurements of Halaphanolaimus rivalis sp.n. (all measurements in $\mu \mathrm{m}$, except ratio)

\begin{tabular}{|c|c|c|c|c|c|}
\hline \multirow{3}{*}{ Characteristics } & \multirow{3}{*}{$\begin{array}{c}\text { Holotype } \\
\delta^{\lambda} \\
\end{array}$} & \multicolumn{4}{|c|}{ Paratypes } \\
\hline & & \multicolumn{2}{|c|}{$7 \delta^{1}$} & \multicolumn{2}{|c|}{390} \\
\hline & & range & mean & range & mean \\
\hline $\mathrm{L}$ & 724 & $686-754$ & 717 & $696-748$ & 719 \\
\hline $\mathrm{a}$ & 30 & $30-37$ & 33 & $30-36$ & 33 \\
\hline $\mathrm{b}$ & 5.3 & $5.3-5.8$ & 5.5 & $5.3-6.1$ & 5.7 \\
\hline $\mathrm{c}$ & 9.9 & $7.8-9.9$ & 8.8 & $7.8-9.0$ & 8.2 \\
\hline$c^{\prime}$ & 4.0 & $4.0-5.8$ & 4.5 & $5.5-7.8$ & 6.8 \\
\hline V\% & - & - & - & $45.7-49.3$ & 47.9 \\
\hline Oesophagus length & 136 & $122-137$ & 130 & $122-132$ & 127 \\
\hline $\begin{array}{l}\text { Posterior end of oesophagus to } \\
\text { vulva }\end{array}$ & - & - & - & $207-224$ & 217 \\
\hline Vulva to anus & - & - & - & $263-308$ & 284 \\
\hline $\begin{array}{l}\text { Posterior end of oesophagus to } \\
\text { cloaca }\end{array}$ & 515 & $476-529$ & 505 & - & - \\
\hline Tail length & 73 & $70-92$ & 82 & $7-98$ & 91 \\
\hline Labial region width & 6.0 & $5.5-6.0$ & 6.0 & $5.5-6.0$ & 6.0 \\
\hline Stoma length & 21 & $19-21$ & 20 & $20-21$ & 20.5 \\
\hline Cephalic setae length & 3.0 & $3.0-3.5$ & 3.0 & $3.0-3.5$ & 3.0 \\
\hline Amphid fovea to body head & 7.5 & $7.0-8.0$ & 7.5 & $6.5-7.5$ & 7.0 \\
\hline Spicules length (along arch) & 28 & $27-28$ & 27.5 & - & - \\
\hline
\end{tabular}

Type locality and habitat: Thi Vai river, mangrove forest Cangio, Hochiminh city, Vietnam. Depth of waters 1,5-4,5 m, fine silt, salinity $16-25 \hat{\mathrm{E}}$.

Type material: holotype male on slide number 50/II and paratypes $1 \hat{\delta}$ and $29 q$ on slide 50b/II deposited at the nematode collection of the Institute of Inland Waters Biology, Borok, Russia. Paratypes $5 \hat{\partial} \hat{O}$ and $1 \propto q Q$ on slide $50 \mathrm{c} / \mathrm{II}$ deposited at the Nematode collection of the Institute of Ecology and Biological
Resources, Vietnamese Academy of Science and Technology, Hanoi, Vietnam

Differential diagnosis: the new species resembles to Halaphanolaimus luridus (Timm, 1963) and L. lorenzeni Boucher, Bovee, 1972, $H$. rivalis sp.n.differs from $H$. luridus by the presence of somatic and cervical setae, more wide labial region ( in $H$. luridus, labial region 4.0-4.5 $\mu \mathrm{m}$ wide $v s$ 5.5-6.0 $\mu \mathrm{m}$ wide in new species ), longer stoma ( in H. luridus, stoma 8 $\mu \mathrm{m}$ long $v s 19=21 \mu \mathrm{m}$ long in new species), 
shorter spicules (in H. luridus, spicules 27-28 $\mu \mathrm{v} v s 35 \mu \mathrm{m}$ long in new species) (Boucher, Bovee, 1972). $H$. rivalis sp.nov differs from $H$. lorenzeni by the thicker body ( in H. lorenzeni, $a=40-45$ vs $a=30-37 \mu \mathrm{m}$ in new species), longer stoma (in H. lorenzeni, stoma 16=17 $\mu \mathrm{m}$ long $v s$ 16-17 $\mu \mathrm{m}$ in new species) and longer spicules ( in $H$. lorenzeni, spicules $16 \mu \mathrm{m}$ long vs 27-28 $\mu \mathrm{m}$ in new species) Lorenzen, 1972.

Etymology: the species name means "creek bank" of the local mangrove forest.

Table 3

Morphometric characters of the valid species of the genus Halaphanolaimus

\begin{tabular}{|l|c|c|c|c|c|c|}
\hline & pellucidus & harpagi & lorenzeni & luridus & cangionensis & rivalis \\
\hline$L . \mu \mathrm{m}$ & $1460-1550$ & $430-518$ & $635-735$ & $520-760$ & $499-571$ & $696-754$ \\
\hline$a$ & $33-41$ & $26-35$ & $40-45$ & $27-37$ & $24-37$ & $30-37$ \\
\hline$b$ & $6.0-6.6$ & $3.8-4.5$ & $5.3-6.1$ & $4.7-5.8$ & $4.7-5.5$ & $5.3-6.1$ \\
\hline$c$ & $10.7-12.7$ & $6.9-8.3$ & $7.4-9.1$ & $6.8-8.7$ & $5.7-7.6$ & $7.8-9.9$ \\
\hline$C \square$ & $3.3-4.6$ & $4.2-5.6$ & $4.5-6.5$ & $4.0-4.5$ & $5.0-8.1$ & $4.0-7.8$ \\
\hline$V . \%$ & 47.9 & $51-53$ & 48 & - & $47.2-50.4$ & $45.7-49.3$ \\
\hline $\begin{array}{l}\text { Somatic and cer. } \\
\text { setae }\end{array}$ & + & + & + & - & - & + \\
\hline Lab region width, $\mu \mathrm{m}$ & 8.0 & $4.0-5.0$ & $5.0-5.5$ & $4.0-4.5$ & $3.5-4.5$ & $5.5-6.0$ \\
\hline Stoma length, $\mu \mathrm{m}$ & $23-25$ & $?$ & $16-17$ & 8 & $14-18$ & $19-21$ \\
\hline Cephalic setae, $\mu \mathrm{m}$ & $3.0-4.0$ & $2.0-3.0$ & $2.0-2.5$ & 3.0 & $1.5-2.0$ & $3.0-3.5$ \\
\hline $\begin{array}{l}\text { Amphid fovea to } \\
\text { body head, } \mu \mathrm{m}\end{array}$ & 10 & $8-9$ & $8-9$ & $7.0-7.5$ & $7.0-8.0$ & $6.6-8.0$ \\
\hline Spicules length, $\mu \mathrm{m}$ & $47-52$ & $15-16$ & 16 & 35 & $16-18$ & $27-28$ \\
\hline Male pre. supplement & $6-7$ & $4-5$ & 4 & 4 & 4 & 4 \\
\hline
\end{tabular}

\section{Key to the valid species of the genus Halaphanolaimus}

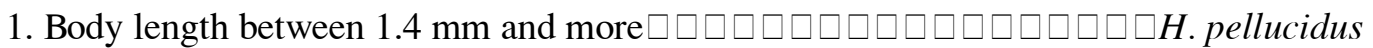

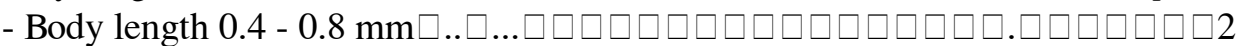

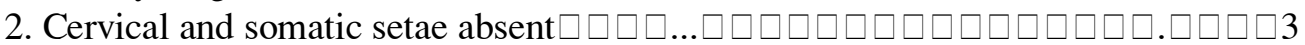

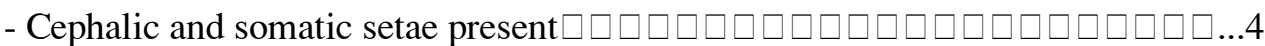

3. Stoma $8 \mu \mathrm{m}$ long; spicules $35 \mu \mathrm{m}$; c' = 4.0-4.5. $\square \square \square \square \square \square \square \square \square \square \square . \square . . . \square \square \square$. luridus

- Stoma 14-18 $\mu \mathrm{m}$ long; spicules 16-18 $\mu \mathrm{m}$ long; c'= 5.0-8.1. $\square \square \square \square$.........H. cangionensis $\mathrm{n} . \mathrm{sp}$

4. Body 0.43-0.52 mm long; $b=3.8-4.5 ; V=51-53 \% \ldots . . . \square \square \square . . \square \square \square \square$... $\square . . \square \square . H$. harpaga

- Body length $0.6 \mathrm{~mm}$ and more; $b=4,7$ and more; $V=47 \%$ and less $\square . . \square \square \square \square . \square \square \square \square \square 5$

5. Stoma 16-17 $\mu \mathrm{m}$ long; $a=40-45$; spicules $16 \mu \mathrm{m}$ long.. $\square \square \square \square \square \square \square \square \square . \square . \square . H$. lorenzeni

- Stoma 19-21 $\mu \mathrm{m}$ long; $a=30-37$; spicules $27-28 \mu \mathrm{m}$ long $\square \square \square \square \square . \square \square \square$.....H. rivalis $\mathrm{n} . \mathrm{sp}$

\section{DISCUSSION}

Nine species of the genus Halaphanolaimus Southern, 1914 were described: H. pellucidus Southern, 1914; H. longisetosus Allgen, 1928; $H$. minutus Stekhoven, 1942; H. norvegicus Allgen, 1945; H. luridus (Timm, 1963); H. harpaga Boucher, Bovee, 1972; H. lorenzeni Boucher, Bovee, 1972; H. cangionensis sp.nov and
H. rivalis sp.nov Afterwards $H$. longisetosus Allgen, 1928 and $H$. norvegicus Allgen, 1946 were transferred to the genus Alaimella Cobb, 1920 (Gerlach et Riemann, 1973). H. minutus Stekhoven, 1942 described for one female only and do not having tubular supplement at oesophagus region, and be transferred to species inquirenda. Boucher, Bovee, 1972 described new species $H$. harpaga and transferred two species 
from the genus Leptolaimus to the genus Halaphanolaimus: $H$. luridus and $H$. lorenzeni. Thus, six valid species of the genus Halaphanolaimus are known at present (table 3).

Acnowledgement: this study was partly supported by the Project Impact of mangrove exploitation of the Benthic ecosystem and the assessment of ecological quality objectives (IMABE) of Belgium. The authors thank the financial assistance from VLIR IMABE Project during the period of study.

\section{REFERENCES}

1. Boucher G., Bovee F., 1972: Vie Milieu, 23(1): 127-132.

2. Gerlach A. S., Riemann F., 1973: Suppl., 4: 1- 404.

3. Lorenzen S., 1972: Kieler Meeresforschungen, 28 (1): 92-93.

4. Tim R. W., 1963: Proceedings of the nematological society, Washington, 30(1): 34- 49.

\title{
HAI LOÀI TUYẾN TRÙNG MỚI THUỘC GIỐNG HALAPHANOLAIMUS DE MAN, 1876 (NEMATODA: LEPTOLAIMIDAE) Ở RƯNG NGẬP MẶN CẦN GIỜ, VIỆT NAM
}

\author{
VLADIMIR G. GAGARIN, NGUYÊ̂̃N VŨ THANH
}

\section{TÓM TÁ́T}

Khu hệ Tuyến trùng nước lợ, Tuyến trùng biển và Tuyến trùng ở hệ sinh thái rừng ngập mặn Việt Nam chỉ mới được nghiên cứu trong mấy năm gần đây. Cho đến nay, trên toàn thế giới, 9 loài thuộc giống Haliphanolaimus Southern, 1914 đã được mô tả là các loài $H$. pellucidus Southern, 1914; H. longisetosus Allgen, 1928; H. minutus Stekhoven, 1942; H. norvegicus Allgen, 1945; H. luridus (Timm, 1963); H. harpaga Boucher, Bovee, 1972; H. lorenzeni Boucher, Bovee, 1972; H. cangionensis sp.nov; $H$. rivalis sp.nov Tuy nhiên hai loài $H$. longisetosus Allgen, 1928 và $H$. norvegicus Allgen, 1946 đã được Gerlach et Riemann, 1973 chuyển sang giống Alaimella Cobb, 1920, Loài H. minutus Stekhoven, 1942 được mô tả chỉ dựa vào 1 con cái và không có nhú sinh dục phụ hình ống tại vùng gần cổ, do vậy được chuyển sang loài chưa đủ cơ sở dữ liệu để mô tả (species inquirenda). Boucher, Bovee, 1972 mô tả loài tuyến trùng mới $H$. harpaga và tu chỉnh giống này với việc chuyển từ giống Leptolaimus sang giống Halaphanolaimus hai loài H.luridus và $H$. lorenzen. Như vậy cộng cả hai loài vừa mô tả tại Việt Nam, trong giống này hiện đã biết 6 loài.

Loài tuyến trùng mới Halaphanolaimus cangionensis sp.nov tương đối giống loài Halaphanolaimus harpaga Boucher, Bovee, 1972 và loài Halaphanolaimus luridus (Timm, 1963), tuy nhiên loài mới khác biệt so với loài $H$. harpaga bởi chúng không có các lông somatic và các lông cổ; vị trí lố sinh dục cũng nằm về nửa trước nhiều hơn (ở loài $H$. harpaga, $\mathrm{V}=51-53 \%$ so với $\mathrm{V}=47,2-50,4 \%$ ở loài mới). Ngoài ra, loài mới cũng có cấu tạo miếng đệm của gai sinh dục rất đặc trưng và cách sắp xếp của các nhú phụ sinh dục (Boucher, Bovee, 1972). Loài mới cũng khác biệt loài $H$. luridus bởi có cấu trúc đuôi dài hơn (ở $H$. luridus, c' $=4,0-4,5$ so với c' $=5,0-8,1$ ở loài mới), xoang miệng dài hơn (ở H. luridus, xoang miệng dài $8 \mu \mathrm{m}$ so với 14-18 $\mu \mathrm{m}$ của loài mới) và có gai sinh dục ngắn hơn (ở H. luridus, gai sinh dục dài $35 \mu \mathrm{m}$ so với 16-18 $\mu \mathrm{m}$ ở loài mới).

Loài Tuyến trùng mới Halaphanolaimus rivalis sp.n. tương đối giống loài Halaphanolaimus luridus (Timm, 1963) và loài L. lorenzeni Boucher, Bovee, 1972, tuy nhiên khác loài H. luridus ở chỗ loài mới có nhiều lông somatic, lông cổ, vùng môi rộng hơn (ở $H$. luridus, vùng môi rộng 4,0-4,5 $\mu \mathrm{m}$ so với 5,5-6,0 $\mu \mathrm{m}$ ở loài mới), loài mới có xoang miệng dài hơn (ở H. luridus, xoang miệng dài $8 \mu \mathrm{m}$ so với 19-21 $\mu \mathrm{m}$ ở loài mới)

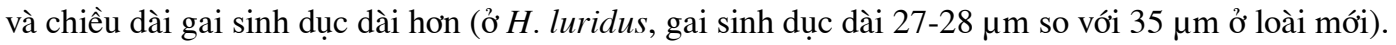

Loài tuyến trùng mới Halaphanolaimus rivalis sp.n. khác biệt so với loài $H$. lorenzeni bởi cơ thể dầy, mập hơn (ở H. lorenzeni, $a=40-45$ so với $a=30-37 \mu \mathrm{m}$ ở loài mới), gai sinh dục dài hơn ( ở loài H. lorenzeni, gai sinh dục dài 16 àm so với 27-28 $\mu \mathrm{m}$ ở loài mới).

Ngày nhận bài: 11-5-2007 